\title{
Yearly thermal performances of solar heating plants in Denmark - Measured and calculated
}

Furbo, Simon; Dragsted, Janne; Perers, Bengt; Andersen, Elsa; Bava, Federico; Nielsen, Kristian Pagh

Published in:

Solar Energy

Link to article, DOI:

10.1016/j.solener.2017.10.067

Publication date:

2018

Document Version

Peer reviewed version

Link back to DTU Orbit

Citation (APA):

Furbo, S., Dragsted, J., Perers, B., Andersen, E., Bava, F., \& Nielsen, K. P. (2018). Yearly thermal performances of solar heating plants in Denmark - Measured and calculated. Solar Energy, 159, 186-196.

https://doi.org/10.1016/..solener.2017.10.067

\section{General rights}

Copyright and moral rights for the publications made accessible in the public portal are retained by the authors and/or other copyright owners and it is a condition of accessing publications that users recognise and abide by the legal requirements associated with these rights.

- Users may download and print one copy of any publication from the public portal for the purpose of private study or research.

- You may not further distribute the material or use it for any profit-making activity or commercial gain

- You may freely distribute the URL identifying the publication in the public portal 


\title{
YEARLY THERMAL PERFORMANCES OF SOLAR HEATING PLANTS IN DENMARK - MEASURED AND CALCULATED
}

\author{
Simon Furbo*, Janne Dragsted*, Bengt Perers*, Elsa Andersen*, Federico Bava* and Kristian Pagh \\ Nielsen** \\ *DTU Civil Engineering, Technical University of Denmark, Brovej, Building 118, 2800 Kgs. Lyngby, Denmark \\ * Tel.: +45 45251857, Email: $\underline{\text { sf@byg.dtu.dk }}$ \\ ** DMI, Lyngbyvej 100, 2100 Kbh Ø, Denmark
}

\begin{abstract}
The thermal performance of solar collector fields depends mainly on the mean solar collector fluid temperature of the collector field and on the solar radiation. For Danish solar collector fields for district heating the measured yearly thermal performances per collector area varied in the period $2012-2016$ between $313 \mathrm{kWh} / \mathrm{m}^{2}$ and $577 \mathrm{kWh} / \mathrm{m}^{2}$, with averages between $411 \mathrm{kWh} / \mathrm{m}^{2}$ and $463 \mathrm{kWh} / \mathrm{m}^{2}$. The percentage difference between the highest and lowest measured yearly thermal performance is about $84 \%$. Calculated yearly thermal performances of typically designed large solar collector fields at six different locations in Denmark with measured weather data for the years 2002-2010 vary between $405 \mathrm{kWh} / \mathrm{m}^{2}$ collector and $566 \mathrm{kWh} / \mathrm{m}^{2}$ collector, if a mean solar collector fluid temperature of $60^{\circ} \mathrm{C}$ is assumed. This corresponds to a percentage difference between the highest and lowest calculated yearly thermal performance of about $40 \%$. This variation is caused by different weather conditions from year to year and from location to location. Approximately half of the variations of yearly thermal performances can be related to variable weather conditions.
\end{abstract}

Keywords: Solar heating plants, yearly thermal performance, solar radiation.

\section{Nomenclature}

$\eta$ collector efficiency, -

$\theta$ incidence angle, ${ }^{\circ}$

$\mathrm{K}_{\theta}$ incidence angle modifier, -

$\mathrm{G}$ solar irradiance on the solar collector, $\mathrm{W} / \mathrm{m}^{2}$

$\mathrm{Gb}$ direct radiation on horizontal, $\mathrm{W} / \mathrm{m}^{2}$

$\mathrm{Rb}$ geometric factor, -

Tm mean solar collector fluid temperature, ${ }^{\circ} \mathrm{C}$

$\mathrm{Ta}$ ambient temperature, ${ }^{\circ} \mathrm{C}$

\section{INTRODUCTION}

The number of solar heating plants in Denmark for district heating has increased strongly in the last couples of years (Windeleff and Nielsen, 2014) and (Bava, Dragsted and Furbo, 2017). Denmark is today frontrunner worldwide on large solar heating plants connected to district heating systems (Weiss, Spörk-Dür and Mauthner, 2017). In 2016 about $500,000 \mathrm{~m}^{2}$ solar collectors were installed in large scale solar heating plants. By the end of 2016, 110 solar heating plants with a total collector area of more than $1,300,000 \mathrm{~m}^{2}$ were in operation. The solar collector fields are based on a high number of parallel connected rows of serial connected collectors mounted on the ground. In most of the solar heating plants flat plate solar collectors are used, see figure 1.

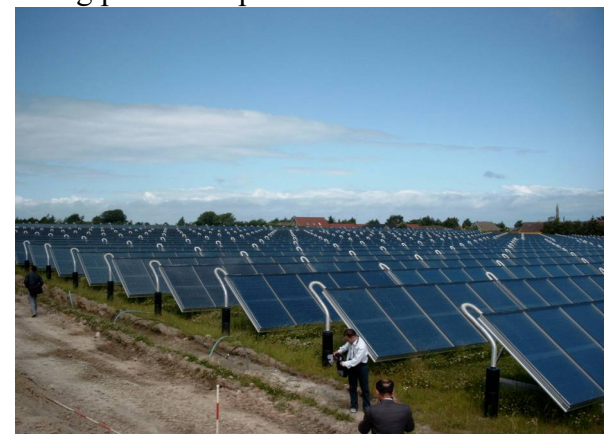

Figure 1. Solar collector field with a high number of rows with flat plate collectors. 
The solar collector fluids in the solar collector loops are propylene glycol/water mixtures. Flat plate heat exchangers are used to transfer the heat produced by the solar collectors from the solar collector fluid to water in the secondary loop. In order to achieve a good cost efficiency of the solar heating plants it is important that the thermal performances of the plants are as high as expected. The heat production of all the solar collector fields is measured.

This paper summarizes measured yearly thermal performances of Danish solar heating plants for the period 2012-2016 as well as theoretically calculated yearly thermal performances of a typical solar heating plant based on measured weather data for different locations in Denmark. The locations of the plants are in the paper indicated by region numbers according to figure 2, which shows six different regions for Demark as suggested by (Wang, Scharling and Nielsen, 2012). The yearly thermal performance vary from plant to plant and for one plant from year to year. This work elucidate how much of the variation are caused by different weather conditions from location to location and from year to year.

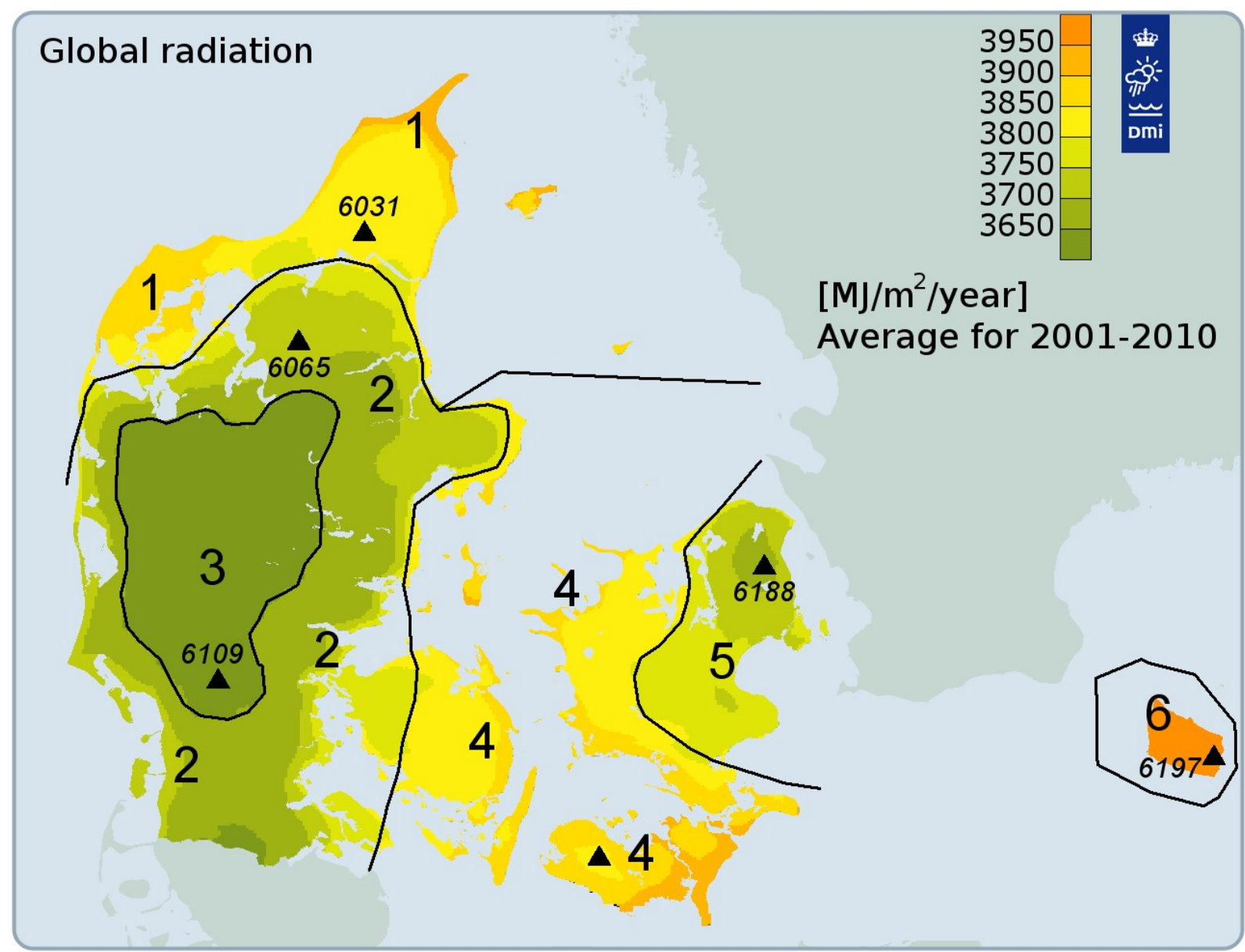

Figure 2. Six Danish regions with different solar radiation.

\section{MEASURED YEARLY THERMAL PERFORMANCES OF SOLAR COLLCTOR FIELDS}

The thermal performances of all Danish solar heating plants are measured. The measurements of the thermal performance are carried out with conventional energy meters in the secondary loop with water as the heat transfer fluid. The solar radiations are typically measured with inexpensive pyranometers on the top of collectors inside the collector fields. Most of the measurements are available on the website www.solvarmedata.dk (2017). Information for most of the solar heating plants, such as collector manufacturer, collector area, ground area of the collector field, collector tilt, year of installation, etc. is also available. The solar collectors in all the solar heating plants face south and the solar collector tilts vary in the interval from $30^{\circ}$ to $45^{\circ}$. Most of the solar heating plants have collector tilts between $35^{\circ}$ and $40^{\circ}$.

Table 1 lists 48 solar heating plants inclusive the region numbers of the locations with available measurements of the thermal performance for all months of 2012, 2013, 2014, 2015 and/or 2016. The solar heating plants were installed in the period 1996-2015. All the plants have flat plate collectors either from ARCON Solar A/S and/or from SUNMARK 
Solutions A/S. Arcon-Sunmark A/S was established in 2015 as the fusion of the two companies. The collector aperture areas of the solar heating plants are in the interval $2970 \mathrm{~m}^{2}-70000 \mathrm{~m}^{2}$. The average solar collector area for the 48 solar heating plants is $12756 \mathrm{~m}^{2}$. The table shows the measured yearly thermal performance, the measured yearly solar radiation on the solar collectors and the yearly utilization of the solar radiation for the solar heating plants for 2012, 2013, 2014, 2015 and/or 2016. The thermal performance and the solar radiation are given per $\mathrm{m}^{2}$ solar collector aperture area. The utilization of the solar radiation is the ratio between the thermal performance of the solar collector field and the solar radiation on the collectors of the solar collector field. Measurements from 16, 21, 31, 36 and 41 plants are available for 2012, 2013, 2014, 2015 and 2016.

The measured yearly thermal performances of the solar heating plants per collector area ranged from $313 \mathrm{kWh} / \mathrm{m}^{2}$ to $577 \mathrm{kWh} / \mathrm{m}^{2}$ with averages for all plants of $411 \mathrm{kWh} / \mathrm{m}^{2}, 450 \mathrm{kWh} / \mathrm{m}^{2}, 463 \mathrm{kWh} / \mathrm{m}^{2}, 439 \mathrm{kWh} / \mathrm{m}^{2}$ and $435 \mathrm{kWh} / \mathrm{m}^{2}$ for 2012, 2013, 2014, 2015 and 2016, respectively. The measured yearly solar radiations on the solar collectors were in the interval $876 \mathrm{kWh} / \mathrm{m}^{2}$ collector $-1474 \mathrm{kWh} / \mathrm{m}^{2}$ collector with averages for all plants of $1102 \mathrm{kWh} / \mathrm{m}^{2}$ collector, 1135 $\mathrm{kWh} / \mathrm{m}^{2}$ collector, $1114 \mathrm{kWh} / \mathrm{m}^{2}$ collector, $1101 \mathrm{kWh} / \mathrm{m}^{2}$ collector and $1153 \mathrm{kWh} / \mathrm{m}^{2}$ collector for 2012, 2013, 2014, 2015 and 2016. The yearly utilizations of the solar radiation were in the interval $27.6 \%-50.8 \%$, with averages for all plants of $37.3 \%, 39.6 \%, 41.6 \%, 39.9 \%$ and $37.9 \%$ for 2012, 2013, 2014, 2015 and 2016. It is estimated that the measured thermal performances and utilizations of the solar radiation for all the plants are satisfactory high.

There are many reasons for the differences in thermal performances between the different solar heating plants. First of all, different weather conditions from location to location and from year to year will influence the yearly thermal performance. (Adsten, Perers and Wäckelgård, 2001) and (Andersen and Furbo, 2009) have for Swedish and Danish locations shown that both the yearly thermal performance of solar collectors and the yearly utilization of solar radiation of solar collectors will increase for increasing yearly solar radiation. This also appear from figure 3 , which for all plants in the different regions for all years shows the yearly thermal performances as functions of the yearly solar radiation on the solar collectors. Further, there are different temperature levels in the different district heating systems. This will result in different temperature levels in the solar collector fields and therefore in different thermal performances. The lower the temperature level is, the higher the thermal performance.

Furthermore, the different solar collector types, the different designs of the solar collector fields, the different control strategies including the different flow rates and maybe the different uneven flow distributions in the solar collector fields will influence the thermal performance. For instance, (Bava and Furbo, 2016) showed that the flow rate will influence the flow distribution and efficiency of solar collectors and (Rohde and Knoll, 1976), (Dorantes, Garcia, Salazar, Oviedo, Gonzalez, Alanis, Salazar and Martin-Dominguez, 2014) and (Bava and Furbo, 2017) showed that the flow rate influence the flow distribution and thermal performance of a solar collector field.

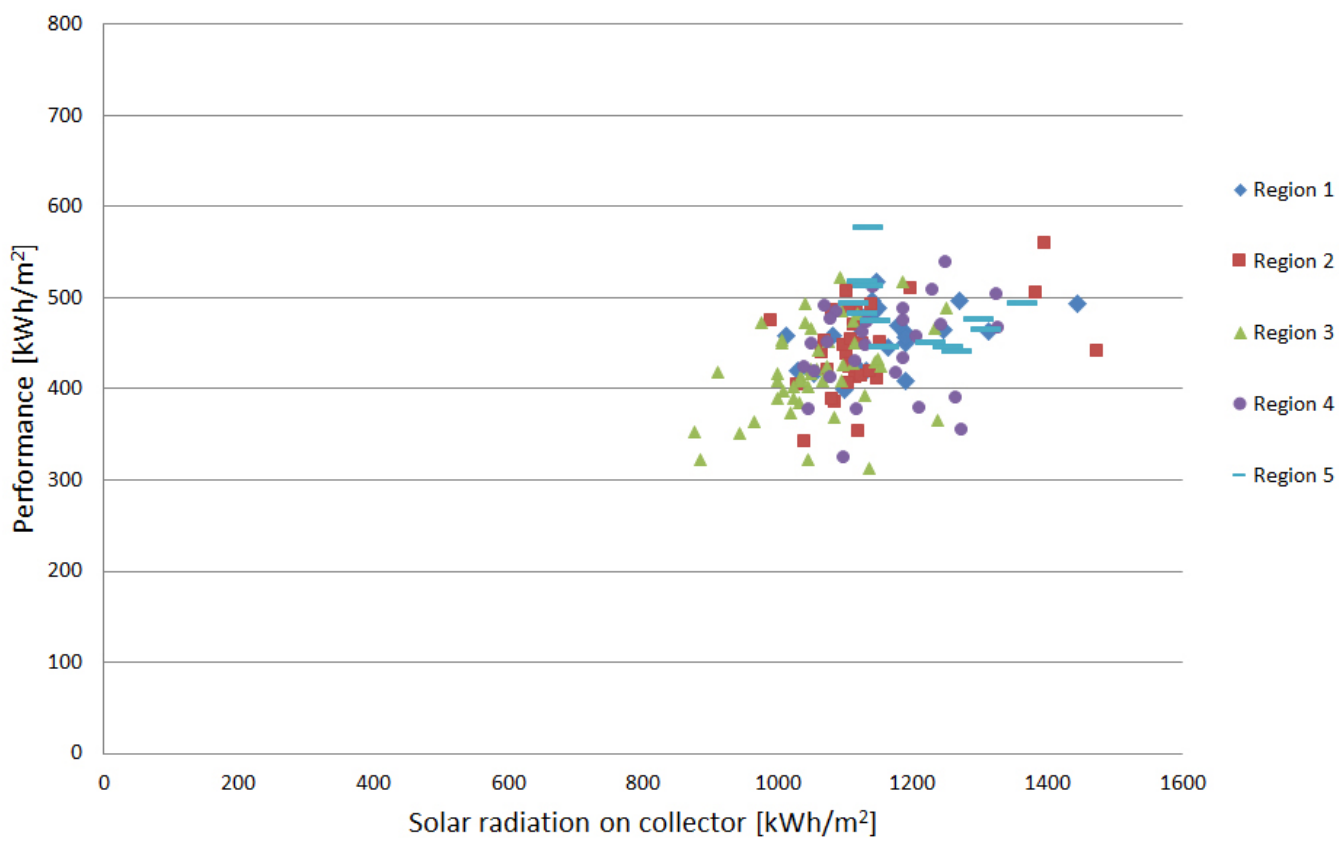

Figure 3. Yearly thermal performances as function of yearly solar radiation on solar collectors for all plants and years. 
Additionally, the different heat losses from the pipes in the solar collector loops, the different collector tilts, the different shading conditions, the different moisture conditions inside the solar collectors, the different snow conditions, and the different dirt conditions on the glass covers of the solar collectors may influence the thermal performance. Finally, some plants have long term heat storages charged at high temperatures during summer resulting in a relatively lower thermal performance per $\mathrm{m}^{2}$ collector.

\section{CALCULATED YEARLY THERMAL PERFORMANCES OF SOLAR COLLECTOR FIELDS}

Yearly thermal performances of a solar collector field have been calculated for the six different Danish locations shown in figure 2. The calculations have been done with a typical marketed solar collector from Arcon-Sunmark A/S, HTHEATstore 35/10 with the efficiency and incidence angle modifier based on the aperture area given by (Månsson and Aronsson, 2016):

$$
\begin{aligned}
& \eta=\mathrm{K}_{\theta} \cdot 0.802-[2.226 \cdot(\mathrm{Tm}-\mathrm{Ta}) / \mathrm{G}]-\left[0.010 \cdot(\mathrm{Tm}-\mathrm{Ta})^{2} / \mathrm{G}\right] \\
& \mathrm{K}_{\theta}=1-\tan ^{3.1}(\theta / 2)
\end{aligned}
$$

The collector has a polymer foil between the absorber and the cover glass.

Calculations are carried out for each location and each year with measured weather data from the period 2002-2010. An hourly value for the global radiation on horizontal is measured for every hour of the years. The method described by (Dragsted and Furbo, 2012) is used to calculate the hourly diffuse and direct radiation on horizontal $\mathrm{G}_{\mathrm{b}}$. The hourly direct radiation on the collector plane is determined by $R_{b} \cdot G_{b}$. The direct radiation on the collectors is decreased by shadows from the collector row in front of the collector row in question. The reduction of direct radiation is proportional to the shaded area in relation to the total collector area of the row.

The diffuse radiation on horizontal is converted to tilted diffuse radiation using a classical isotropic model, and both diffuse radiation from the sky and from the ground are taken into account. Inside the collector field the diffuse radiation is reduced due to the shading from the collector row in front using view angles from the collector to the sky and to the ground from the middle height of the collector row. Solar angles in the middle of the hour in question are used in the calculations. The diffuse and direct radiation determined as described above as well as the incidence angle for direct radiation are used together with the collector efficiency to determine the hourly thermal performance of the solar collector field. It is estimated that the method will give reasonably accurate results.

A solar collector field with 20 collector rows with $35^{\circ}$ tilted collectors facing south is assumed. The row distance is $5.5 \mathrm{~m}$ and shadows from one row to the next are considered.

Figures 4 and 5 show the results for the nine years period 2002-2010. These include the measured yearly global radiation on horizontal, the calculated total yearly radiation on the collectors and the calculated yearly thermal performance of the collector field as a function of the mean solar collector fluid temperature which is assumed constant during all operation periods for region 1, see figure 2. Further, the values for the design reference year for the region (Wang, Scharling and Nielsen, 2012) are included in the figures. The performance ratio included in figure 5 is defined as the ratio between the thermal performance of the solar collector field for the year in question and the thermal performance of the solar collector field for the reference year for the region.

Quantities similar to the quantities shown for region 1 are shown for region 2, 3, 4, 5 and 6 in figures 6-15. It should be mentioned that solar radiation measurements for 2004 for region 5 are not available and therefore omitted. 


\begin{tabular}{|c|c|c|c|c|c|c|c|c|c|c|c|c|c|c|c|}
\hline \multirow{3}{*}{$\begin{array}{l}\begin{array}{l}\text { Solar heating } \\
\text { plant/region } \\
\text { number }\end{array} \\
\text { Mou/1 }\end{array}$} & \multicolumn{5}{|c|}{ Solar radiation, $\mathrm{kWh} / \mathrm{m}^{2}$} & \multicolumn{5}{|c|}{ Thermal performance, $\mathrm{kWh} / \mathrm{m}^{2}$} & \multicolumn{5}{|c|}{ Utilization of solar radiation, $\%$} \\
\hline & 2012 & 2013 & 2014 & 2015 & 2016 & $\begin{array}{l}2012 \\
2016\end{array}$ & & 2014 & \multicolumn{2}{|c|}{2015} & 2012 & 2013 & 2014 & 2015 & 2016 \\
\hline & - & - & 1179 & 1268 & 1245 & - & - & 470 & 497 & 464 & - & - & 39.9 & 39.1 & 37.3 \\
\hline Ulsted/1 & 1163 & 1190 & - & - & 1188 & 445 & 450 & - & - & 408 & 38.3 & 37.8 & - & - & 34.3 \\
\hline Dronninglund/1 & - & - & - & 1054 & 1113 & - & - & - & 417 & 426 & - & - & - & 39.6 & 38.3 \\
\hline Aså/1 & - & - & - & 1140 & 1118 & - & - & - & 496 & 470 & - & - & - & 43.5 & 42.0 \\
\hline Jerslev/1 & - & - & - & - & 1312 & - & - & - & - & 463 & - & - & - & - & 35.3 \\
\hline Sæby/1 & 1030 & 1149 & 1013 & 1188 & 1131 & 420 & 488 & 459 & 461 & 420 & 40.8 & 42.5 & 45.3 & 38.8 & 37.1 \\
\hline Jetsmark/1 & - & - & - & - & 1188 & - & - & - & - & 456 & - & - & - & - & 38.4 \\
\hline Vrå/1 & - & - & - & - & 1099 & - & - & - & - & 399 & - & - & - & - & 36.3 \\
\hline Strandby/1 & 1123 & 1082 & 1140 & 1146 & 1444 & 481 & 458 & 484 & 518 & 493 & 42.8 & 42.3 & 42.5 & 45.2 & 34.1 \\
\hline Broager/2 & 1085 & 1075 & 1474 & 1066 & 1127 & 385 & 420 & 445 & 439 & 449 & 35.5 & 39.1 & 30.2 & 41.2 & 39.8 \\
\hline Gråsten/2 & - & 1103 & 1114 & 1099 & 1115 & - & 438 & 469 & 447 & 412 & - & 39.7 & 42.1 & 40.7 & 37.0 \\
\hline Toftlund/2 & - & - & - & - & 1148 & - & - & - & - & 410 & - & - & - & - & 35.7 \\
\hline Christianfeld/2 & - & - & 1103 & 1081 & 1117 & - & - & 506 & 485 & 481 & - & - & 45.9 & 44.9 & 43.1 \\
\hline Vojens/2 & - & 1124 & 1107 & 1039 & 1029 & - & 414 & 427 & 342 & 404 & - & 36.8 & 38.6 & 32.9 & 39.2 \\
\hline Gram/2 & 1081 & 1138 & 1397 & - & - & 388 & 419 & 557 & - & - & 35.9 & 36.8 & 39.9 & - & - \\
\hline Oksbøl/2 & 1106 & - & 1152 & 1104 & 1121 & 423 & - & 451 & 405 & 353 & 38.2 & - & 39.1 & 36.7 & 31.5 \\
\hline Ringkøbing/2 & 1110 & 1139 & 991 & 1198 & 1383 & 453 & 492 & 474 & 510 & 505 & 40.8 & 43.2 & 47.8 & 42.6 & 36.5 \\
\hline Tim/2 & - & - & 1106 & 1071 & - & - & - & 489 & 452 & - & - & - & 44.2 & 42.2 & - \\
\hline Gørding/3 & - & 1118 & 1091 & - & - & - & 482 & 522 & - & - & - & 43.1 & 47.8 & - & - \\
\hline Hejnsvig/3 & 942 & - & 1022 & 965 & 1008 & 351 & - & 390 & 361 & 397 & 37.3 & - & 38.2 & 37.4 & 39.4 \\
\hline $\mathrm{Sig} / 3$ & - & - & - & 1044 & 1084 & - & - & - & 323 & 369 & - & - & - & 31.0 & 34.0 \\
\hline Tistrup/3 & 1005 & 1039 & 1005 & 1000 & 1070 & 453 & 473 & 450 & 409 & 413 & 45.1 & 45.5 & 44.8 & 40.9 & 38.6 \\
\hline Skovlund/3 & - & 1143 & 1066 & 885 & - & - & 429 & 408 & 322 & - & - & 37.5 & 38.3 & 36.4 & - \\
\hline Tørring/3 & 1129 & 1233 & 1111 & 911 & - & 392 & 466 & 474 & 418 & - & 34.7 & 37.8 & 42.7 & 45.9 & - \\
\hline Brædstrup/3 & 1135 & 1153 & 1046 & 1097 & 1249 & 313 & 425 & 403 & 426 & 489 & 27.6 & 36.9 & 38.5 & 38.8 & 39.2 \\
\hline Ejstrupholm/3 & 1049 & 1095 & 1048 & 1039 & 975 & 422 & 485 & 467 & 494 & 473 & 40.2 & 44.3 & 44.6 & 47.5 & 48.5 \\
\hline Tarm/3 & - & - & 1075 & 1031 & - & - & - & 452 & 385 & - & - & - & 42.0 & 37.3 & - \\
\hline $\begin{array}{l}\text { Ørnhøj- } \\
\text { Grønbjerg/3 }\end{array}$ & - & 1095 & 1059 & 1023 & 1048 & - & 409 & 442 & 402 & 417 & - & 37.4 & 41.7 & 39.3 & 39.8 \\
\hline Vildbjerg/3 & - & - & - & 1148 & 1184 & - & - & - & 433 & 517 & - & - & - & 37.7 & 43.7 \\
\hline Feldborg/3 & - & 1072 & 998 & 876 & 1018 & - & 425 & 417 & 352 & 373 & - & 39.6 & 41.8 & 40.2 & 36.6 \\
\hline Frederiks/3 & - & - & 1033 & 1033 & 1000 & - & - & 414 & 409 & 390 & - & - & 40.1 & 39.6 & 39.0 \\
\hline Karup/3 & - & - & 1113 & 1111 & 1057 & - & - & 450 & 428 & 422 & - & - & 40.4 & 38.5 & 39.9 \\
\hline Haderup/3 & - & - & - & - & 1237 & - & - & - & - & 365 & - & - & - & - & 29.5 \\
\hline Hundested/4 & - & - & - & - & 1250 & - & - & - & - & 538 & - & - & - & - & 43.0 \\
\hline $\begin{array}{l}\text { Nykøbing } \\
\text { Sjælland/4 }\end{array}$ & - & - & - & 1325 & 1327 & - & - & - & 503 & 466 & - & - & - & 38.0 & 35.1 \\
\hline Østervang/4 & - & - & - & - & 1131 & - & - & - & - & 447 & - & - & - & - & 39.5 \\
\hline Svebøl-Viskinge/4 & - & - & 1039 & 1142 & 1099 & - & - & 423 & 511 & 324 & - & - & 40.7 & 44.7 & 29.5 \\
\hline Hvidebæk/4 & - & - & 1186 & 1207 & 1186 & - & - & 474 & 457 & 432 & - & - & 40.0 & 37.9 & 36.4 \\
\hline Sydfalster/4 & 1087 & 1070 & 1079 & 1230 & 1126 & 484 & 491 & 476 & 508 & 462 & 44.5 & 45.9 & 44.1 & 41.3 & 41.0 \\
\hline Sydlangeland/4 & - & - & 1132 & 1051 & 1186 & - & - & 472 & 448 & 487 & - & - & 41.7 & 42.7 & 41.1 \\
\hline Marstal/4 & 1046 & 1055 & 1116 & 1078 & - & 377 & 419 & 429 & 412 & - & 36.0 & 39.7 & 38.4 & 38.2 & - \\
\hline St. Rise/4 & - & - & - & 1177 & 1118 & - & - & - & 416 & 376 & - & - & - & 35.3 & 33.6 \\
\hline Ærøskøbing/4 & 1274 & 1264 & - & - & 1210 & 355 & 389 & - & - & 378 & 27.9 & 30.8 & - & - & 31.2 \\
\hline Grenå/4 & - & - & - & 1244 & 1074 & - & - & - & 469 & 451 & - & - & - & 37.7 & 42.0 \\
\hline Vejby/5 & - & - & 1136 & 1127 & 1134 & - & - & 577 & 517 & 512 & - & - & 50.8 & 45.9 & 45.1 \\
\hline Helsinge/5 & - & 1126 & 1114 & 1145 & 1159 & - & 483 & 493 & 475 & 446 & - & 42.9 & 44.3 & 41.9 & 38.5 \\
\hline Jægerspris/5 & 1267 & 1363 & 1300 & 1309 & 1251 & 441 & 493 & 476 & 464 & 446 & 34.8 & 36.2 & 36.6 & 35.4 & 35.7 \\
\hline Skuldelev/5 & - & - & - & - & 1227 & - & - & - & - & 451 & - & - & - & - & 36.8 \\
\hline Average & 1102 & 1135 & 1114 & 1101 & 1153 & 411 & 450 & 463 & 439 & 435 & 37.3 & 39.6 & 41.6 & 39.9 & 37.9 \\
\hline
\end{tabular}




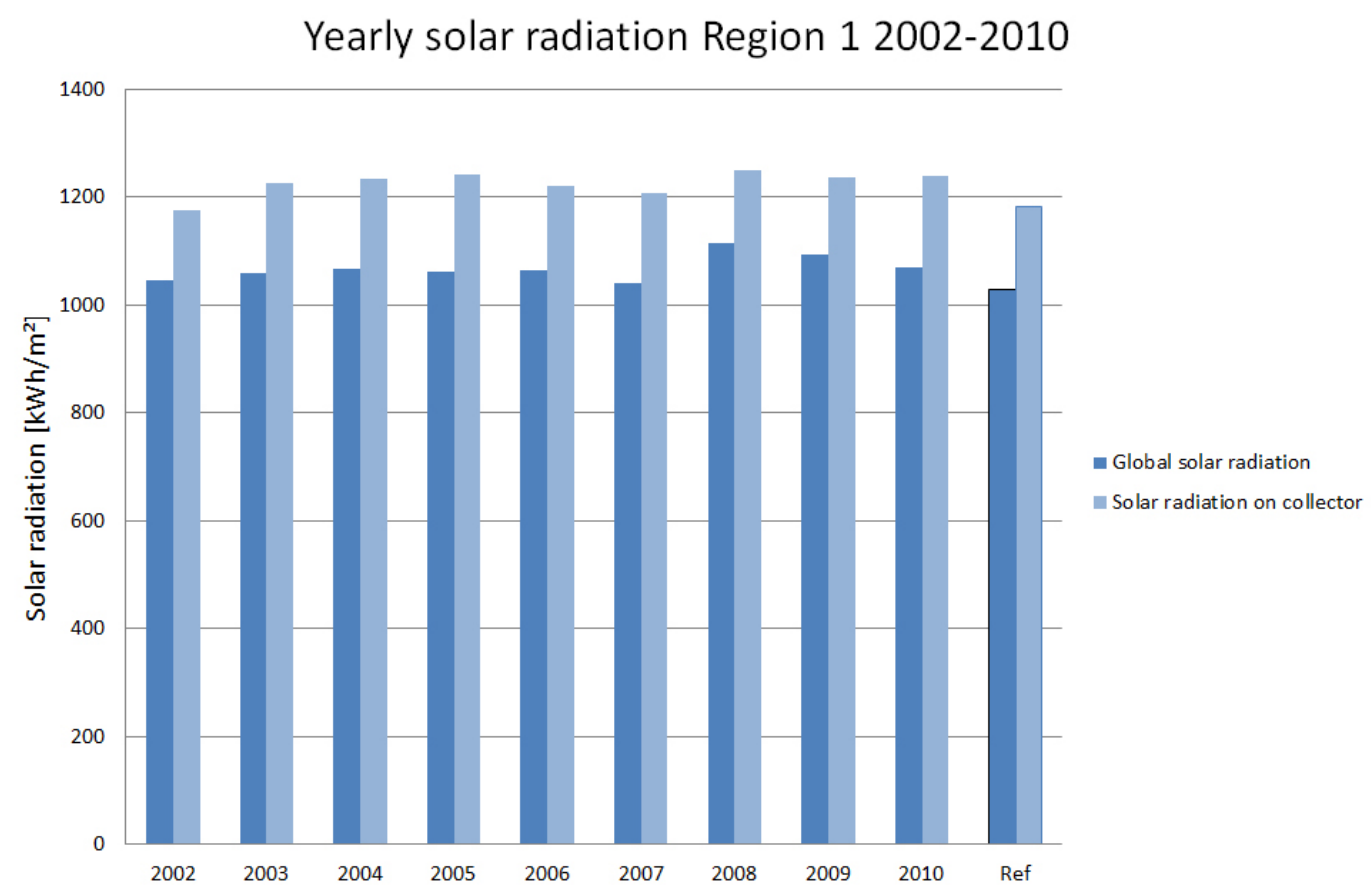

Figure 4. Measured yearly global radiation and calculated yearly solar radiation on collectors for region 1.

Performance Region 1 2002-2010

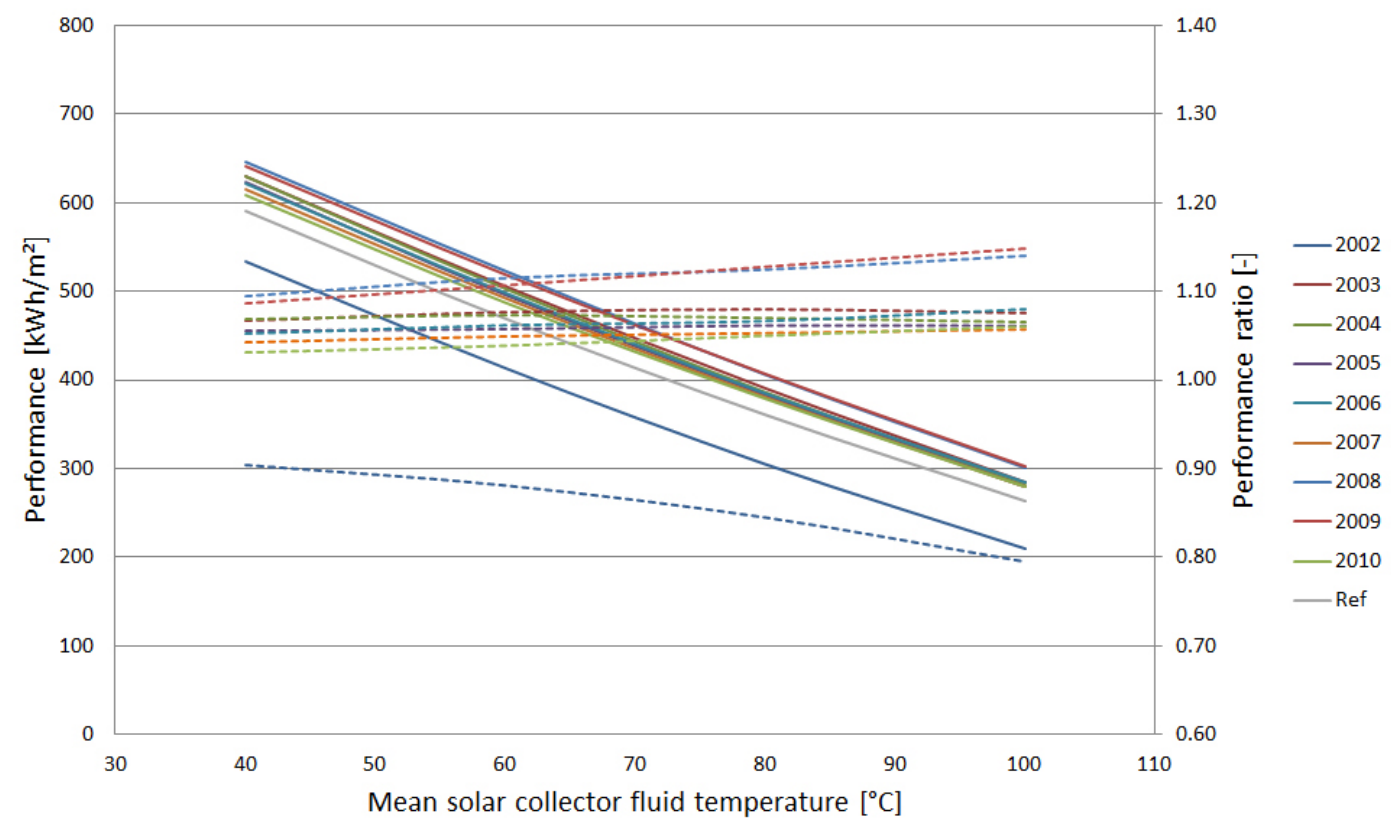

Figure 5. Calculated yearly thermal performance of a collector field for region 1. 


\section{Yearly solar radiation Region 2 2003-2010}

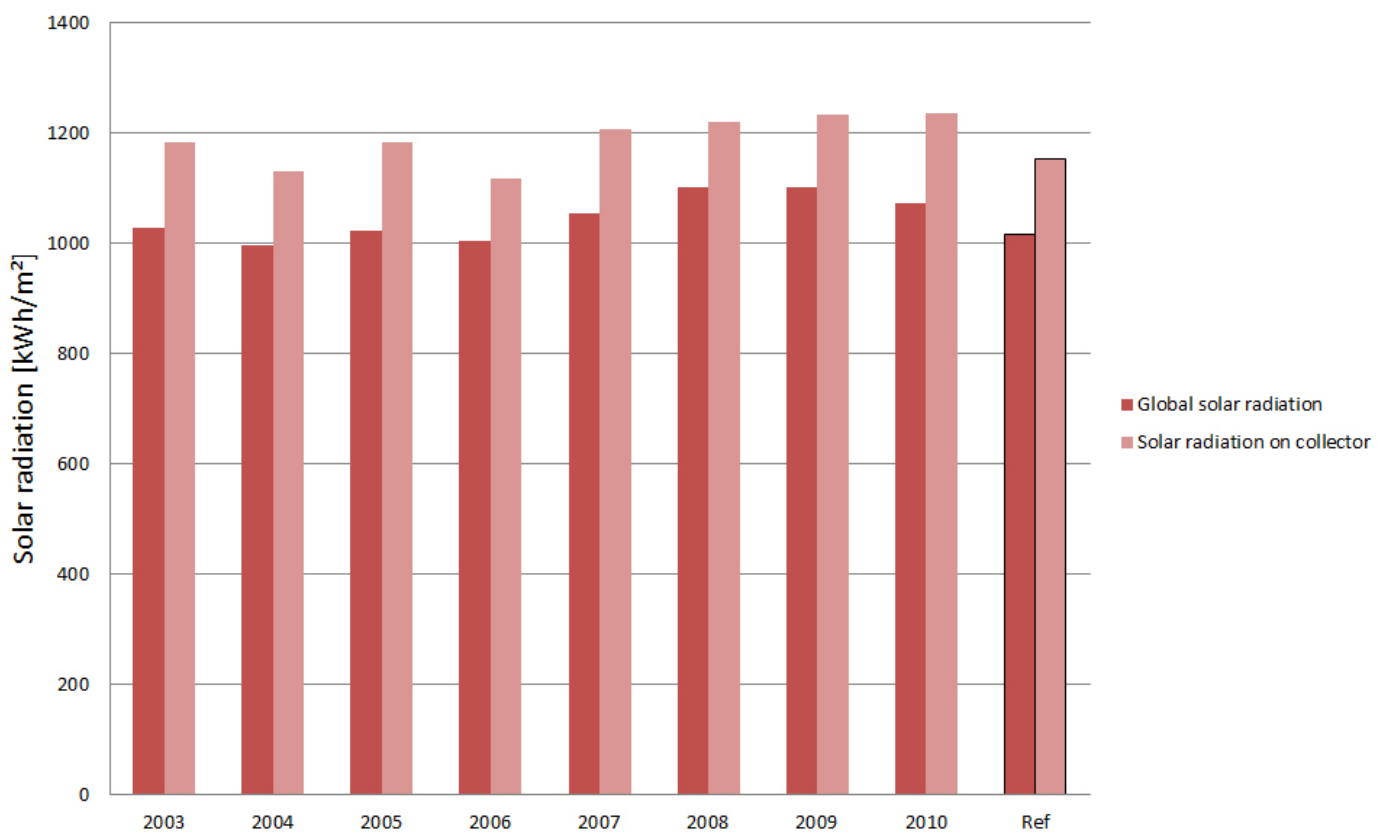

Figure 6. Measured yearly global radiation and calculated yearly solar radiation on collectors for region 2 .

Performance Region 2 2003-2010

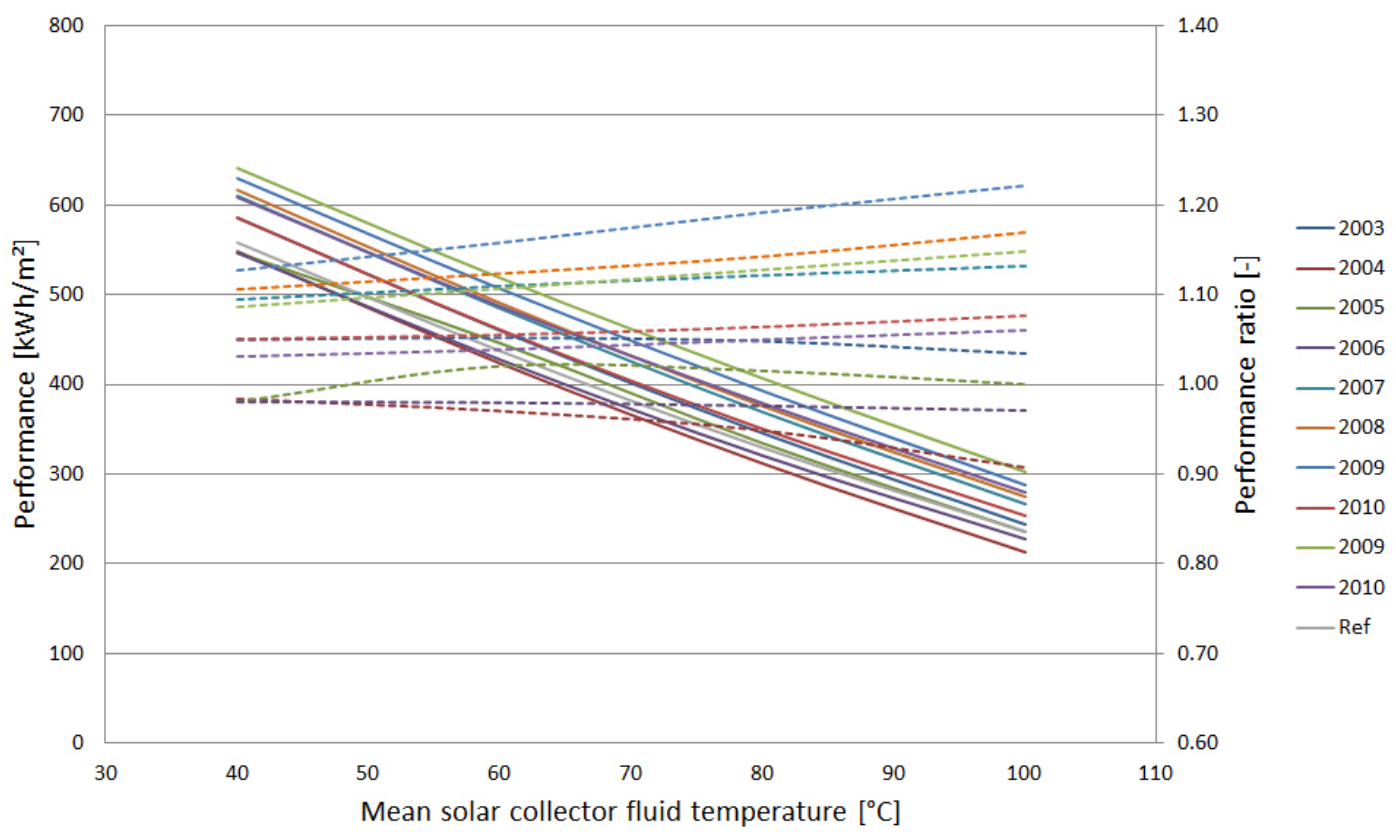

Figure 7. Calculated yearly thermal performance of a collector field for region 2. 


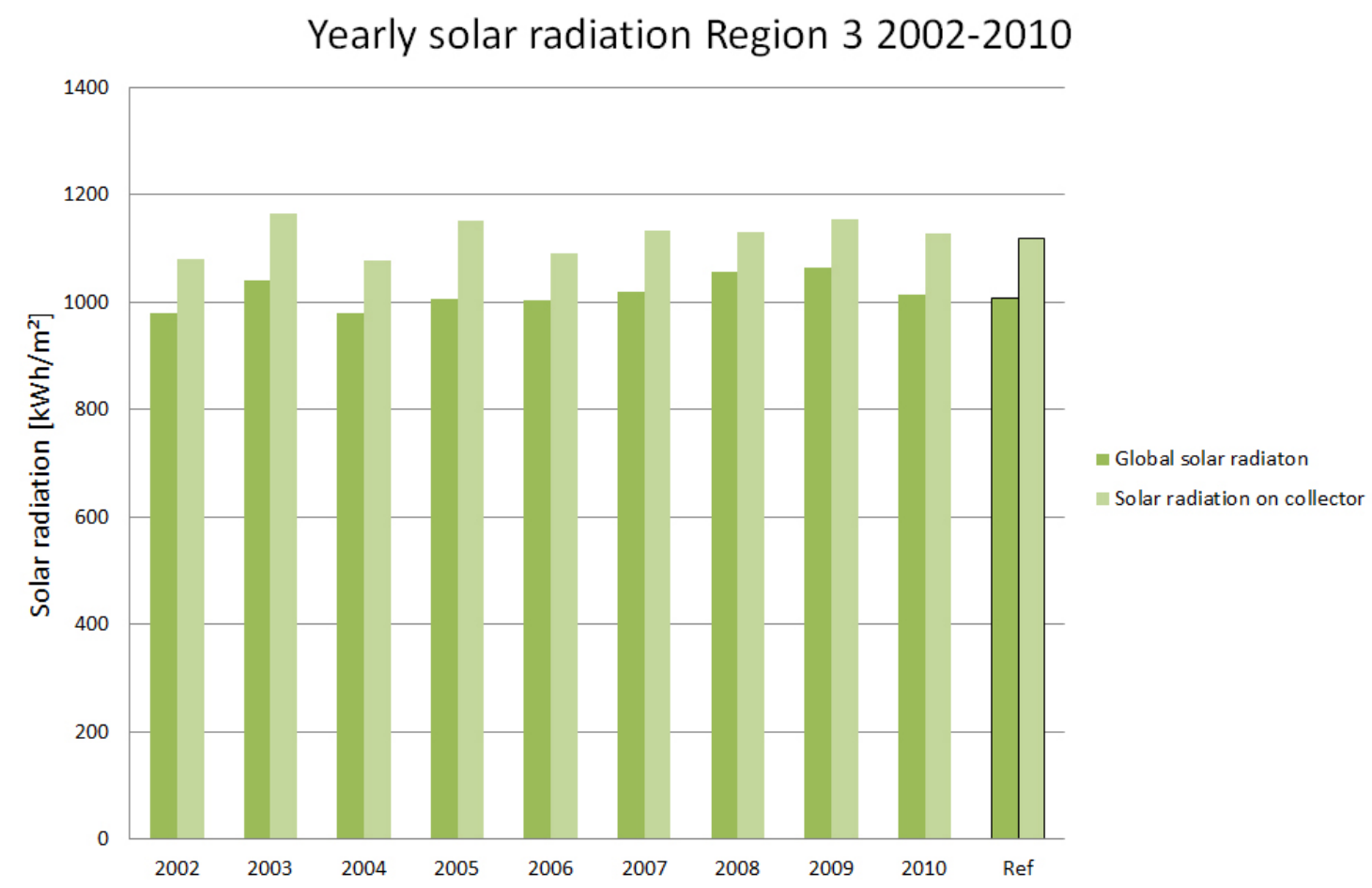

178

Figure 8. Measured yearly global radiation and calculated yearly solar radiation on collectors for region 3.

Performance Region 3 2002-2010

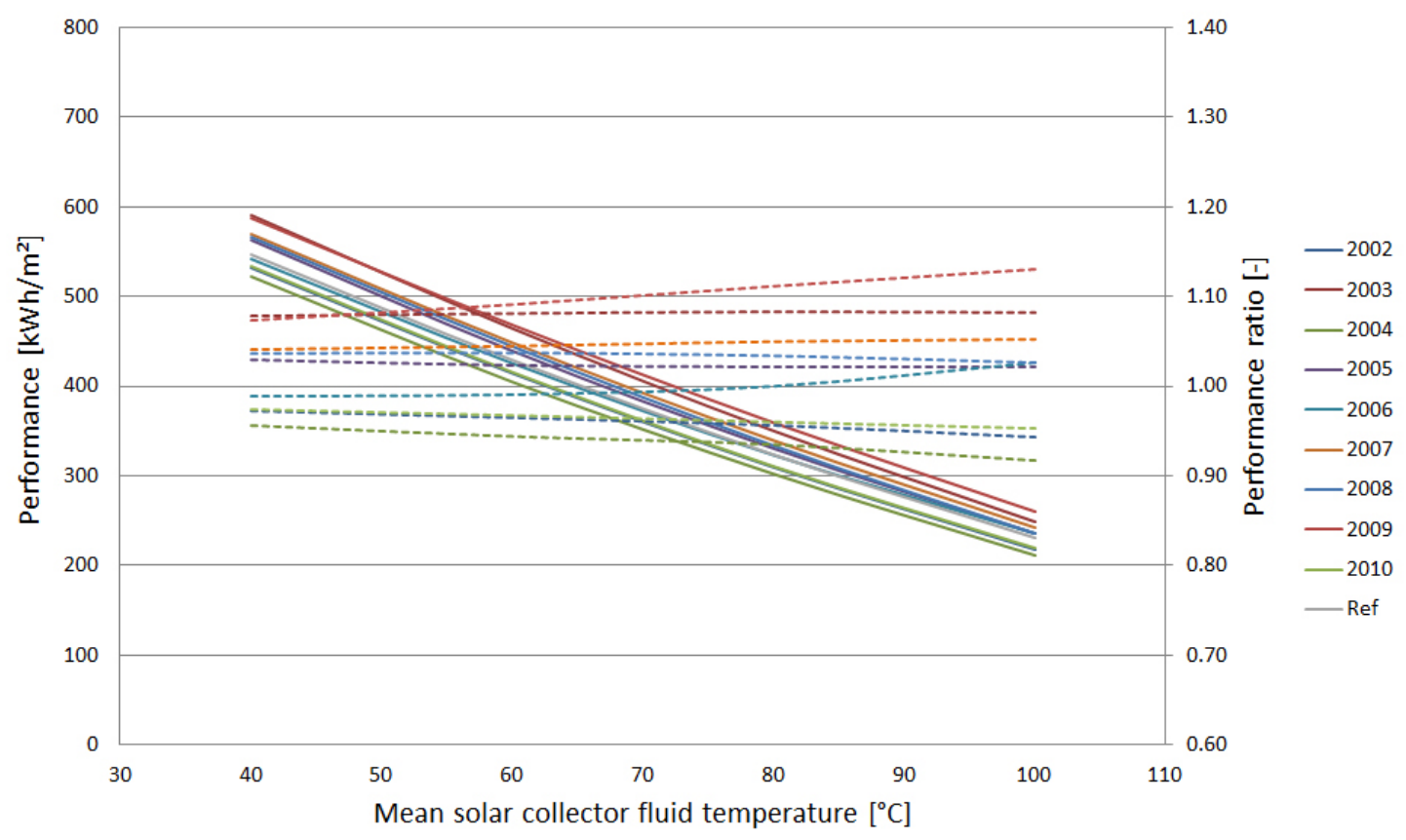

Figure 9. Calculated yearly thermal performance of a collector field for region 3. 


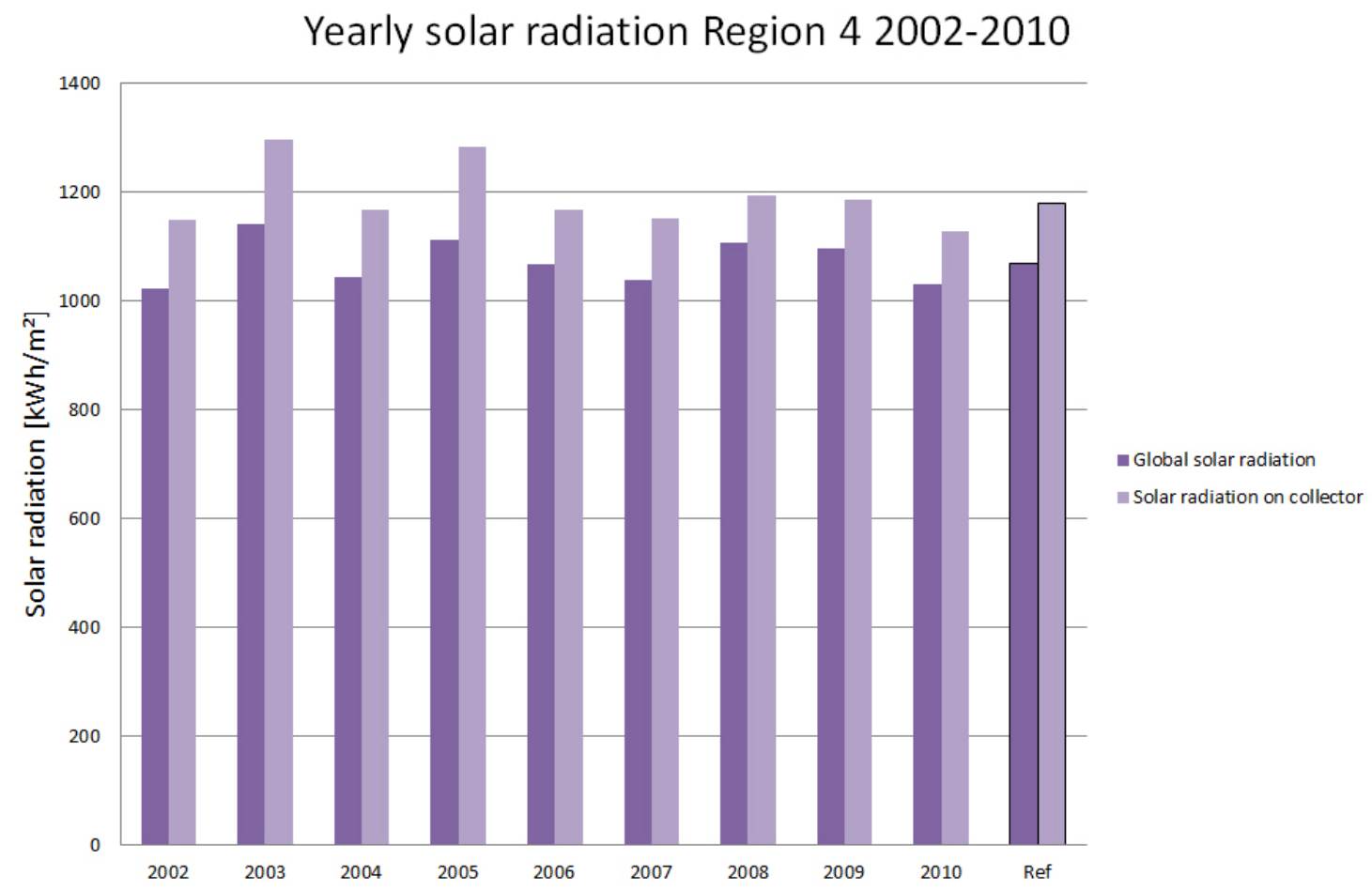

Figure 10. Measured yearly global radiation and calculated yearly solar radiation on collectors for region 4.

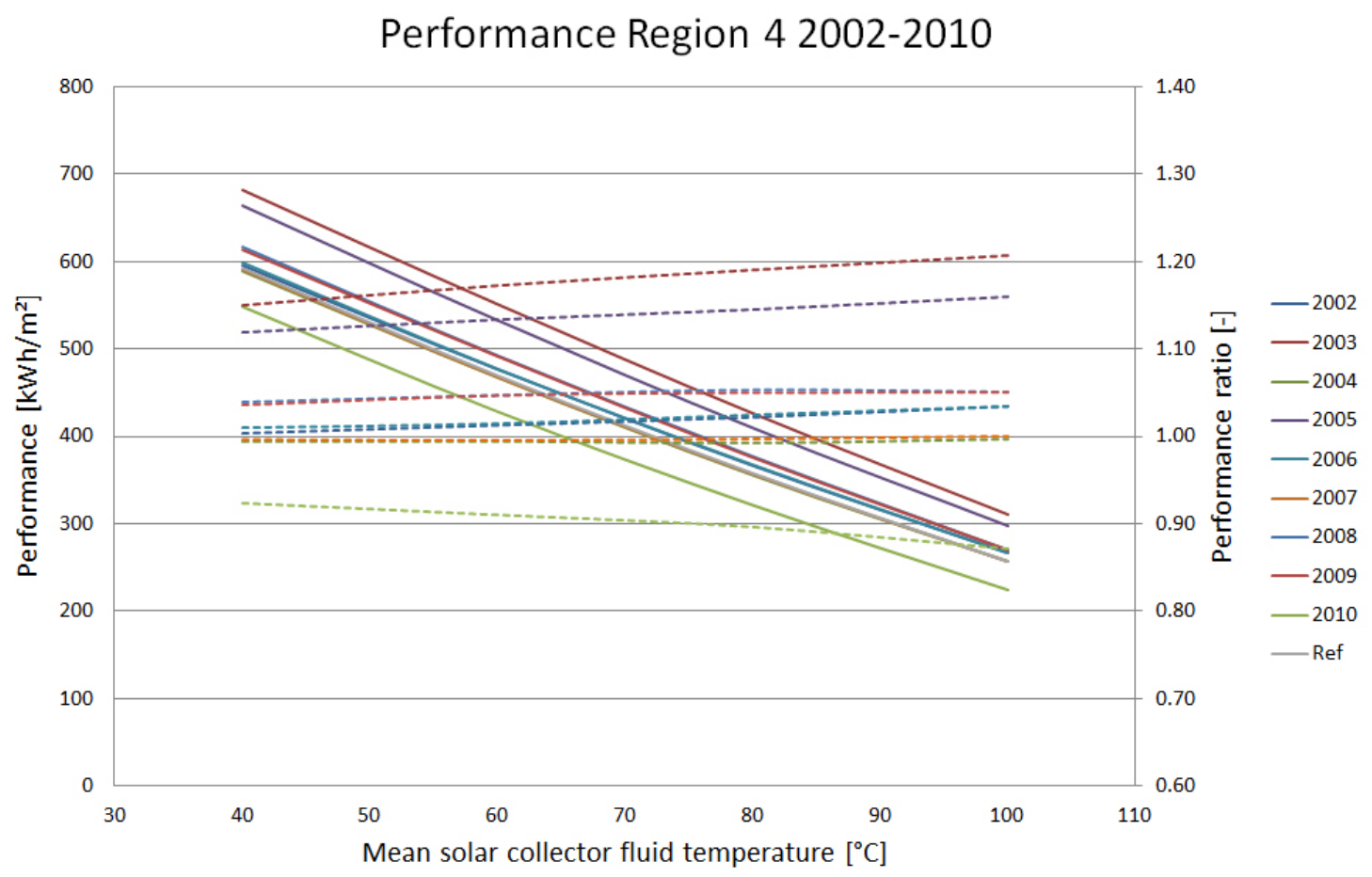

Figure 11. Calculated yearly thermal performance of a collector field for region 4. 
Yearly solar radiation Region 5 2002-2010

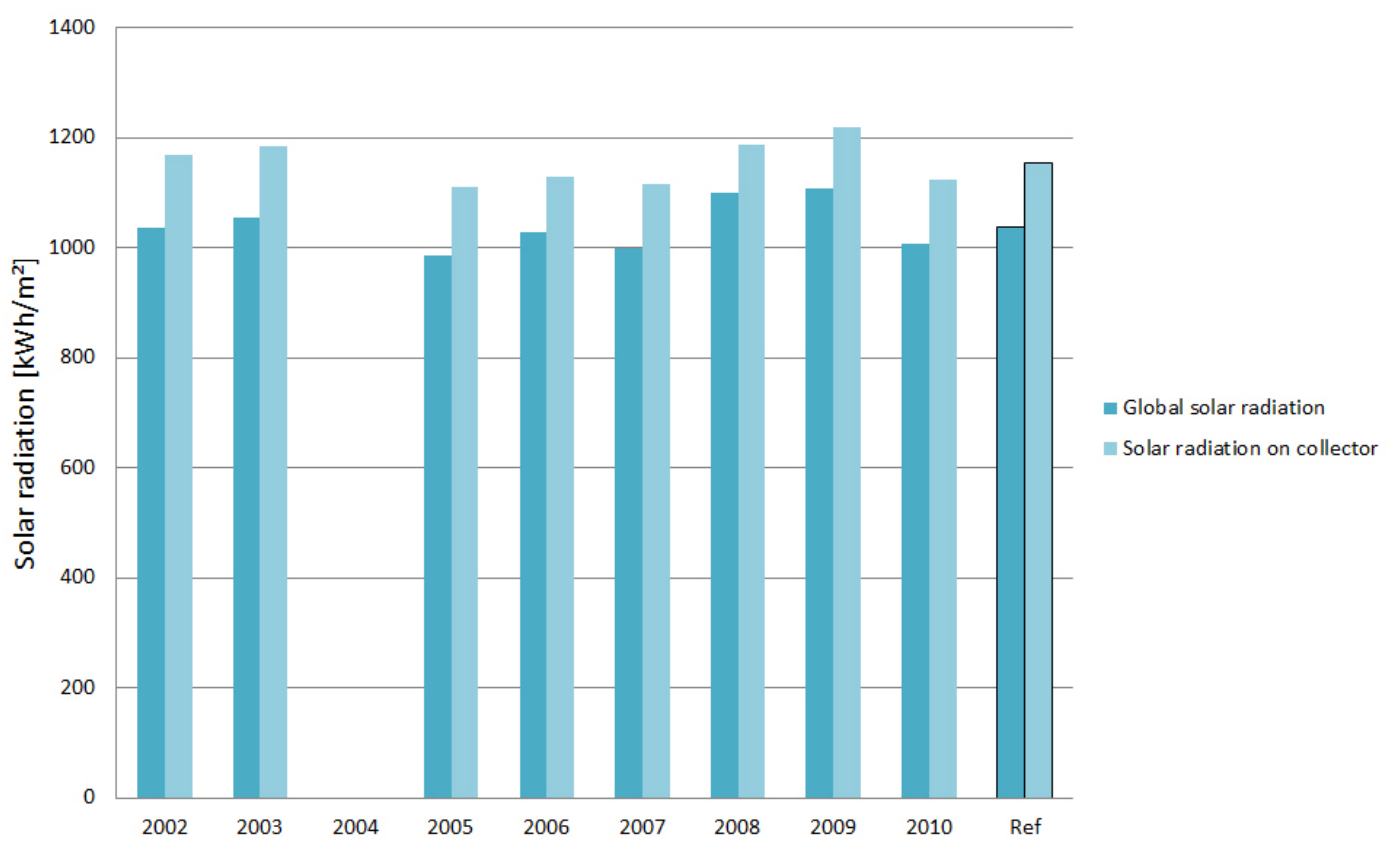

Figure 12. Measured yearly global radiation and calculated yearly solar radiation on collectors for region 5.

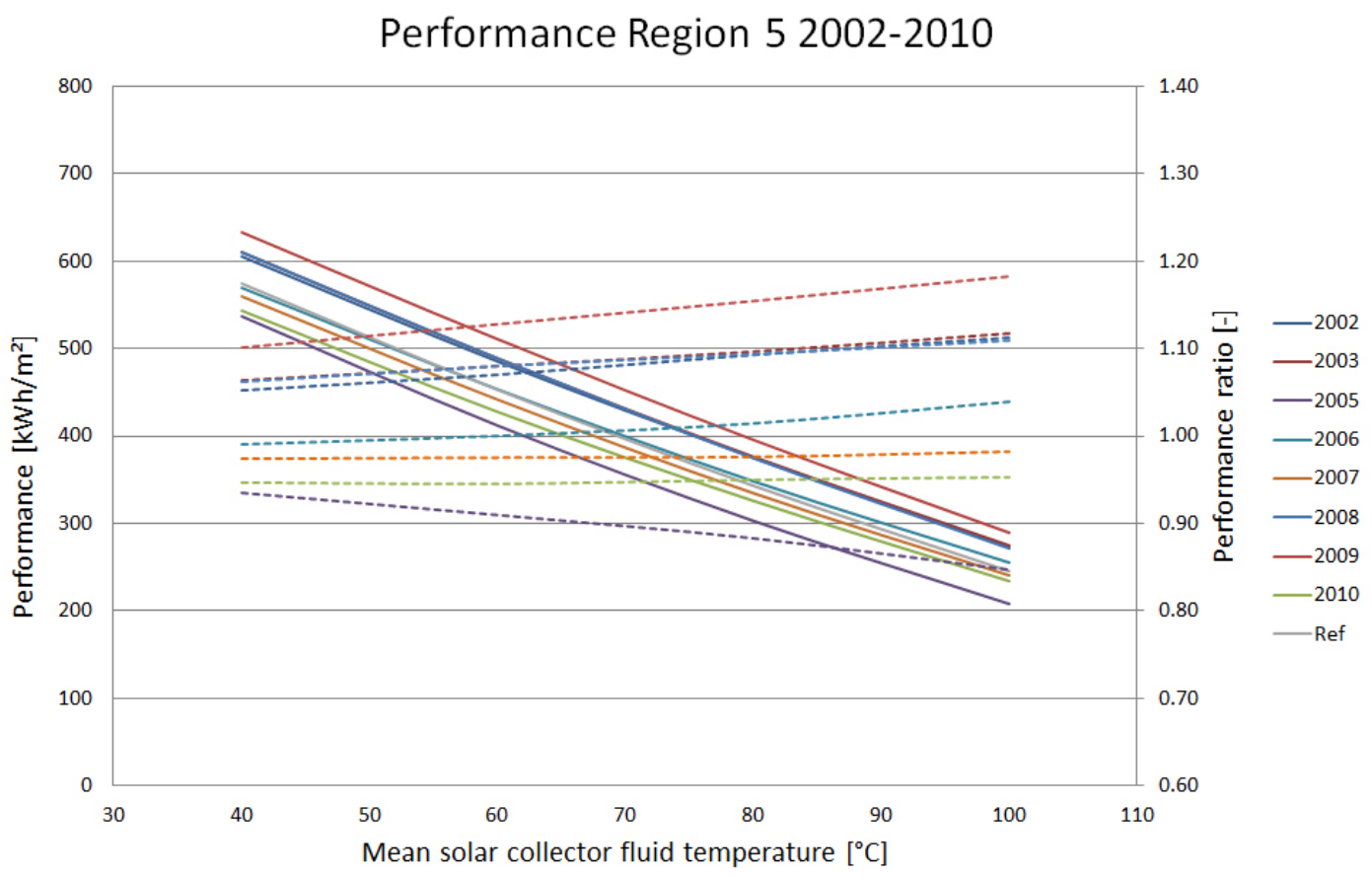

Figure 13. Calculated yearly thermal performance of a collector field for region 5. 


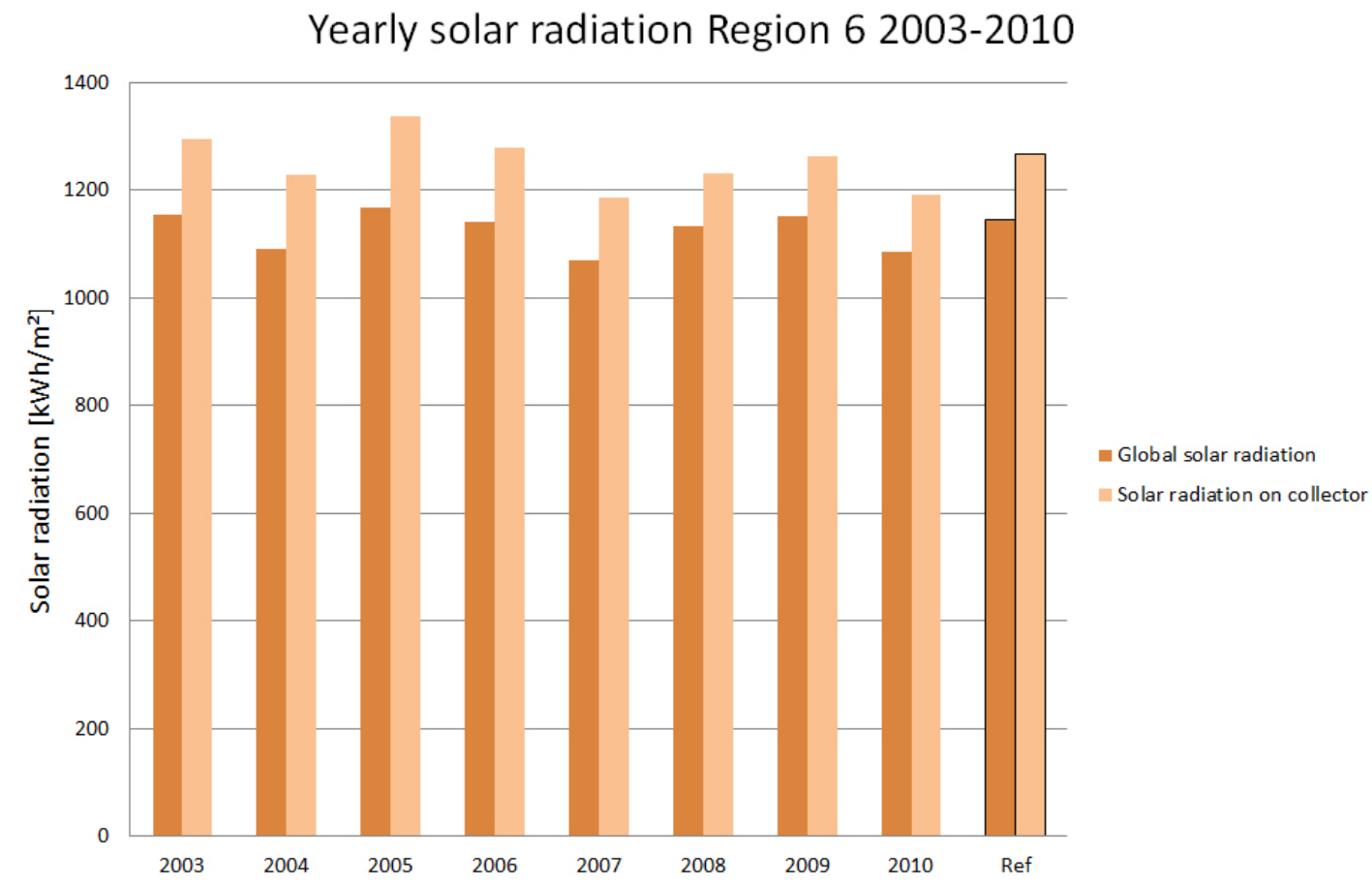

Figure 14. Measured yearly global radiation and calculated yearly solar radiation on collectors for region 6 .

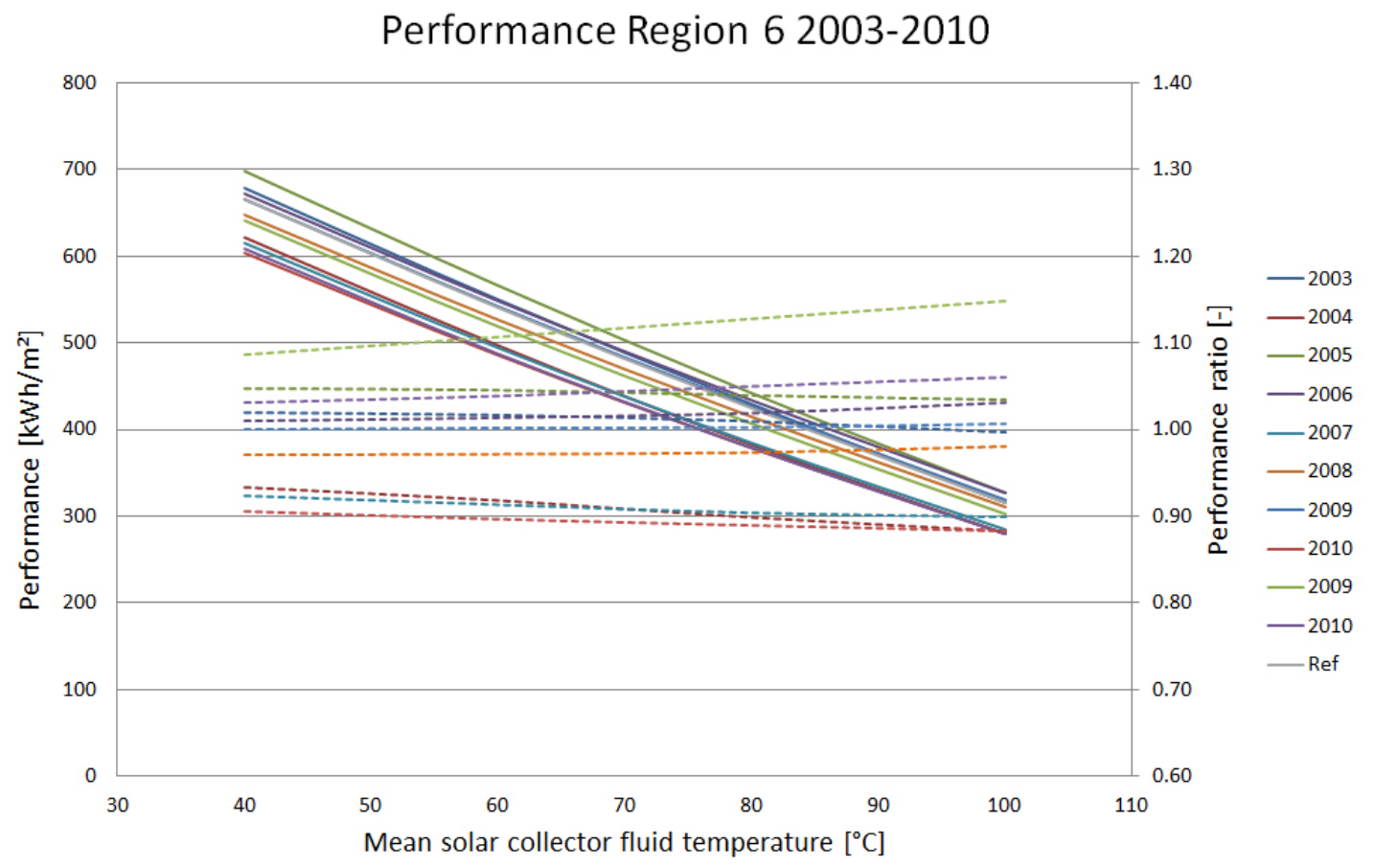

Figure 15. Calculated yearly thermal performance of a collector field for region 6 . 


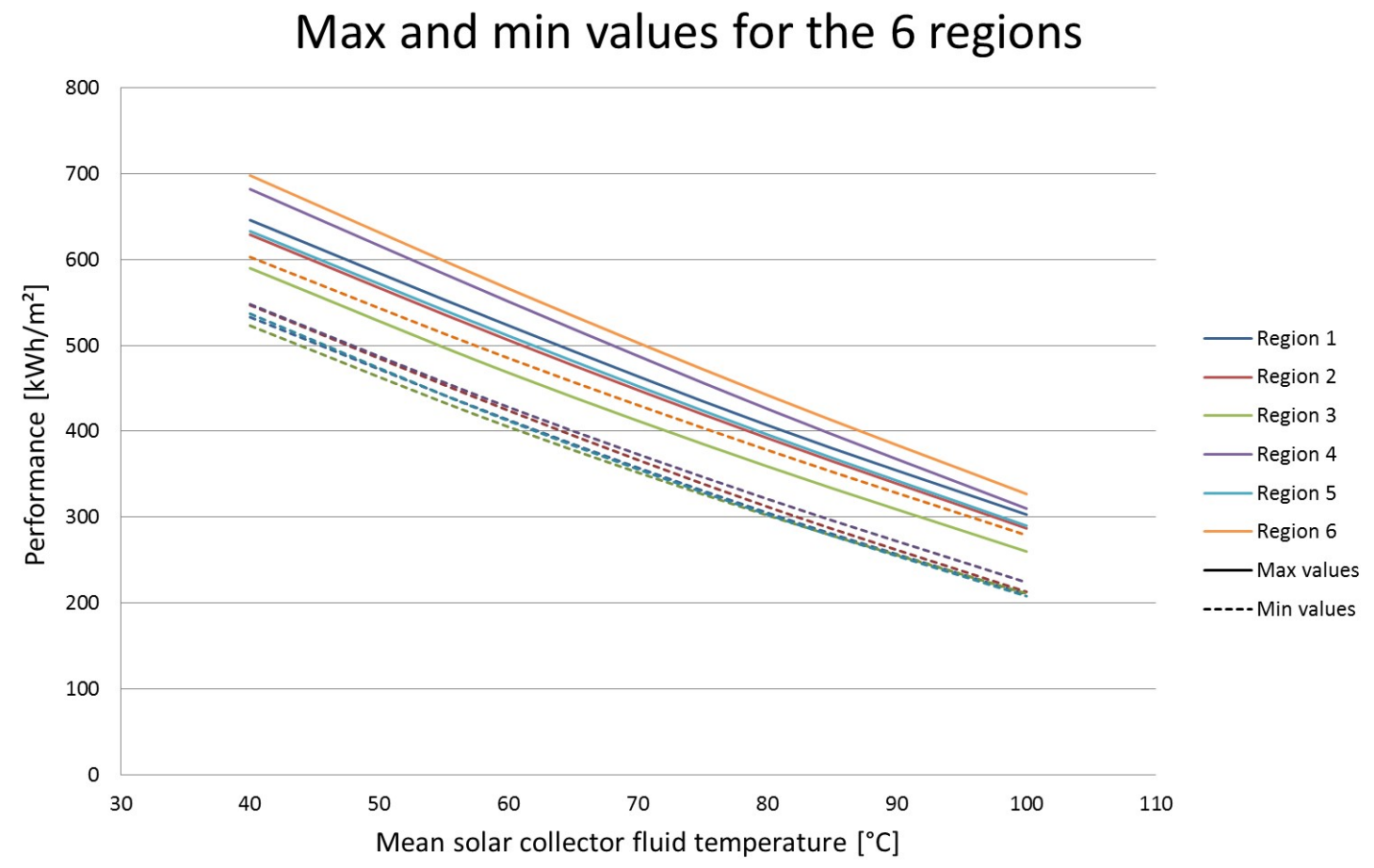

Figure 16. Calculated highest and lowest yearly thermal performance for the Danish regions as a function of the mean solar collector fluid temperature.

Figure 16 shows the highest and lowest yearly thermal performances for all six regions as a function of the mean solar collector fluid temperature.

The measured yearly global radiations on horizontal are in the interval $980 \mathrm{kWh} / \mathrm{m}^{2}-1150 \mathrm{kWh} / \mathrm{m}^{2}$. The highest yearly global radiation is $17 \%$ higher than the lowest yearly global radiation. The highest yearly global radiation is measured in region 6 , Bornholm for 2005 . The lowest yearly global radiation is measured in region 3 , the inner parts of Jutland for 2004.

Based on the hourly global radiation measurements, the hourly solar radiations on the collectors are calculated. Shadows from the row placed in front of the collectors are considered. The calculated yearly solar radiations on the collectors are in the interval $1077 \mathrm{kWh} / \mathrm{m}^{2}-1337 \mathrm{kWh} / \mathrm{m}^{2}$. The highest yearly solar radiation on the collectors is $24 \%$ higher than the lowest yearly solar radiation on the collectors. Again, the highest yearly solar radiation on the collectors is for region 6, Bornholm for 2005 and the lowest yearly solar radiation on the collectors is for region 3 , the inner parts of Jutland for 2004.

The yearly thermal performance is strongly influenced by the mean solar collector fluid temperature. For decreasing temperature, the yearly thermal performance is increasing and the percentage differences between the yearly thermal performances from year to year are decreasing.

It is seen that the yearly thermal performances of the solar collectors typically are highest in region 6 , Bornholm followed by regions 1 and 4, the northern part of Jutland and Funen \& the western part of Zealand, region 5, the eastern part of Zealand, region 2, parts of Jutland close to the coastline and last region 3, the inner parts of Jutland.

The highest and lowest yearly thermal performances for the solar collector field with a mean solar collector fluid temperature of $60^{\circ} \mathrm{C}$ are listed in table 2 for the six regions. 


\begin{tabular}{|l|l|l|l|}
\hline Region & $\begin{array}{l}\text { Highest } \\
\text { thermal } \\
\text { performance, } \\
\mathrm{kWh} / \mathrm{m}^{2} \\
\text { collector }\end{array}$ & $\begin{array}{l}\text { Lowest } \\
\text { thermal } \\
\text { performance, } \\
\mathrm{kWh} / \mathrm{m}^{2} \\
\text { collector }\end{array}$ & $\begin{array}{l}\text { Ratio between } \\
\text { highest and } \\
\text { lowest yearly } \\
\text { thermal } \\
\text { performance, - }\end{array}$ \\
\hline 1 & 523 & 413 & 1.27 \\
\hline 2 & 506 & 424 & 1.19 \\
\hline 3 & 468 & 405 & 1.16 \\
\hline 4 & 551 & 428 & 1.29 \\
\hline 5 & 511 & 412 & 1.24 \\
\hline 6 & 566 & 485 & 1.17 \\
\hline
\end{tabular}

Table 2. Calculated highest and lowest yearly thermal performances of solar collector field for the period 2002-2010 for six regions with a mean solar collector fluid temperature of $60^{\circ} \mathrm{C}$.

For a mean solar collector fluid temperature of $60^{\circ} \mathrm{C}$ the yearly thermal performance is in the interval $405 \mathrm{kWh} / \mathrm{m}^{2}$ collector - $566 \mathrm{kWh} / \mathrm{m}^{2}$ collector. The lowest thermal performance is calculated for 2004 for region 3, the inner parts of Jutland. The highest calculated thermal performance is for 2005 for region 6, Bornholm. The highest yearly thermal performance is $40 \%$ higher than the lowest yearly thermal performance.

The percentage differences between the highest and lowest yearly thermal performance of the collectors are lowest in region 3, the inner parts of Jutland, followed by region 6, Bornholm, region 2, parts of Jutland close to the coastline, region 5, the eastern part of Zealand, region 1, the northern part of Jutland, and last region 4, Funen \& the western part of Zealand.

\section{CONCLUSIONS}

The thermal performance of solar collector fields per collector area depends mainly on the mean solar collector fluid temperature of the collector field and on the solar radiation. Measured yearly thermal performances per collector area of Danish large solar collector fields varied in the period 2012-2016 between $313 \mathrm{kWh} / \mathrm{m}^{2}$ and $577 \mathrm{kWh} / \mathrm{m}^{2}$ with averages for all plants of $411 \mathrm{kWh} / \mathrm{m}^{2}, 450 \mathrm{kWh} / \mathrm{m}^{2}, 463 \mathrm{kWh} / \mathrm{m}^{2}, 439 \mathrm{kWh} / \mathrm{m}^{2}$ and $435 \mathrm{kWh} / \mathrm{m}^{2}$ for 2012, 2013, $2014,2015 \mathrm{and}$ 2016, respectively.

The percentage difference between the highest and lowest measured yearly thermal performance is about $84 \%$.

Calculated yearly thermal performances per collector area of typically designed large solar collector fields at six different locations in Denmark with measured weather data for the years 2002-2010 vary between $405 \mathrm{kWh} / \mathrm{m}^{2}$ and 566 $\mathrm{kWh} / \mathrm{m}^{2}$, if a mean solar collector fluid temperature of $60^{\circ} \mathrm{C}$ is assumed. This corresponds to a percentage difference between the highest and lowest calculated yearly thermal performance of about $40 \%$. This variation is caused by different weather conditions from year to year and from location to location. Half of the variations of yearly thermal performances of the plants can be related to variable weather conditions.

\section{Acknowledgements}

The authors wish to thank the Danish Energy Agency who supported the research through the EUDP program.

\section{REFERENCES}

Adsten M., Perers B., Wäckelgård E., 2001. The influence of climate and location on collector performance. Renewable Energy 25, pp. 499-509.

Andersen E., Furbo S., 2009. Theoretical variations of the thermal performance of different solar collectors and solar combi systems as function of the varying yearly weather conditions in Denmark. Solar Energy, Vol. 83, Number 4, pp. $552-565$

Bava F., Dragsted J., Furbo S., 2017. A numerical model to evaluate the flow distribution in a large solar collector field. Solar Energy 143 (2017), pp. 31-42. 
Bava F., Furbo S., 2016. A numerical model for pressure drop and flow distribution in a solar collector with horizontal U-connected pipes. Solar Energy 134, pp. 264-272.

Dorantes R., Garcia G. Salazar, C., Oviedo H., Gonzalez H., Alanis R., Salazar E., Martin-Dominguez I.R., 2014. Thermal and hydraulic design of a solar collector field for a primary school pool. Energy Proc. 57, pp. 2515-2524. http://dx.doi.org/10.1016/j.egypro.2014.10.262.

Dragsted J., Furbo S., 2012. Solar radiation and thermal performance of solar collectors for Denmark. Department of Civil Engineering, Technical University of Denmark. Report R-275.

Månsson L., Aronsson L., 2016. Certificate Solar Keymark certificate No. SP SC0843-14, http://www.estif.org/solarkeymark/Links/Internal_links/SP/SC0843-14.pdf, SP Technical research Institute of Sweden.

Rohde J.E., Knoll, R.H., 1976. Analyses of a solar collector field water flow network. Lewis Research Center, Cleveland (Ohio, USA). https://ntrs.nasa.gov/archive/nasa/casi.ntrs.nasa.gov/19760024583.pdf.

Wang P.R., Scharling M., Nielsen K.P., 2012. 2001-2010 Design Reference Year for Denmark, beta.dmi.dk/fileadmin/Rapporter/TR/tr12-17.pdf, Technical Report 12-17, DMI, Copenhagen, Denmark.

Weiss W., Spörk-Dür M., Mauthner F., 2017. Solar Heat Worldwide. Global Market Development and Trends 2016. Detailed Market Figures 2015. SHC Solar Heating \& Cooling Programme, International Energy Agency, Edition 2017.

Windeleff J., Nielsen J.E., 2014. Solar district heating in Denmark. Danish Energy Agency and PlanEnergi. www.solvarmedata.dk, 2017. 